\title{
The Investigation of the Effects of Tamoxifen and Vitamin D Combination on the Expression of P53, Bcl-2 and Bax and Cell Cycle in Mcf-7 Cell Line ${ }^{\dagger}$
}

\author{
Derya Yetkin 1, Ebru Ballı 1, Gülsen Bayrak ${ }^{1, *}$, Deniz Kibar ${ }^{1}$ and Merve Türkegün ${ }^{2}$ \\ 1 Department of Histology and Embryology, Mersin University, Mersin, 33300, Turkey; \\ deryayetkin84@gmail.com (D.Y.); ebru_balli@yahoo.com (E.B.); dkibar@mersin.edu.tr (D.K.) \\ 2 Department of Biostatistics and Medical Informatics, Mersin University, Mersin, 33300, Turkey; \\ merveturkegun@gmail.com \\ * Correspondence: gulsenyilmaz61@gmail.com \\ + Presented at the 2nd International Cell Death Research Congress, Izmir, Turkey, 1-4 November 2018. \\ Published: 6 December 2018
}

\begin{abstract}
Breast cancer is the leading type of cancer in women. The majority of cells in the diagnosis of breast cancer are estrogen receptor alpha (ER $\alpha$ ) positive and the growth of these tumors is due to estrogen. Tamoxifen is used as a supportive treatment method in breast cancer patients. Vitamin D is a group of sterols with hormone-like functions. Vitamin D is known to have anti-proliferative effect and is known to induce cell arrest and apoptosis in the G0/G1 phase in the cell cycle. This study aims to investigate the potential anti-carcinogenic effect of different concentrations of Tamoxifen and vitamin $\mathrm{D}$, which are thought to have anti-proliferative effect on breast cancer cell line. In our study, combination of different concentrations of Tamoxifen and vitamin D was evaluated. As a result of the data obtained, cell cycle was studied in FACS ARIA III device. In addition, the expression of p53, BcL-2 and Bax proteins was examined in qRT PCR. In our study, low concentrations of Tamoxifen and vitamin $\mathrm{D}$ increased proliferation in cancer cells. An effective concentration was found for Tamoxifen. Vitamin D alone did not reduce cell proliferation but decreased cell proliferation with combination. As a result, it was found that therapies using these two agents separately decreased the proliferation of cancer cells and induced cell arrest in the G0/G1 phase in the cell cycle and changed the expressions of p53, BcL-2 and Bax proteins.
\end{abstract}

Keywords: breast cancer; tamoxifen; vitamin D

\section{Introduction}

Cancer is an increasing disease in the world in recent years. Cancer-related death worldwide is immediately followed by cardiovascular diseases [1]. Breast cancer accounts for $30 \%$ of cancer cases in women and accounts for $18 \%$ of all cancer deaths [2]. Despite the development of many anticancer drugs against this disease, death rates continue to increase [3]. The majority of the cells in the diagnosis of breast cancer are estrogen receptor alpha positive (ER $\alpha+)$, and their growth and progression is mediated by estrogen. The treatment modalities of these ER $\alpha+$ tumors are progressing to target estrogen-mediated signals with anti-estrogens. Tamoxifen (TAM) is a selective estrogen receptor modulator (SERM) that acts as an antiestrogen in breast cancer cells and has been used for thirty years as a supportive treatment method in breast cancer patients [4]. Vitamin D is a group of sterols with hormone-like functions [5]. Vitamin D receptors (VDRs) are found in many tumor and tumor-derived cell lines such as malignant breast, prostate, epidermal, thyroid, hemapoietic cancers and retinoblastoma. This study aims to investigate the potential anti- 
carcinogenic effect of different concentrations of Tamoxifen and vitamin D, which are thought to have anti-proliferative effect, on breast cancer cell line, MCF-7.

\section{Materials \& Methods}

Real-time Cell Proliferation Analysis: In this study, xCELLigence device was used for cytotoxicity test. In this analysis the viability of the cells with different doses of Tamoxifen and Vitamin D $(20 \mu \mathrm{M}$ Tam + $50 \mathrm{nM}$ vit $\mathrm{D}, 20 \mu \mathrm{M}$ Tam $+100 \mathrm{nM}$ vit $\mathrm{D}, 10 \mu \mathrm{M}$ Tam $+50 \mathrm{nM}$ vit $\mathrm{D}, 10 \mu \mathrm{M}$ Tam $+100 \mathrm{nM}$ vit D) were evaluated. For cytotoxicity analysis, cells were cultivated in E-plates upon the addition of related compounds and the computed-based system connected to the device automatically record the data to give "cell index/time" graph.

Cell Cycle Analysis: As a result of the data obtained from real-time cell proliferation assay, cell cycle was studied by use of FACS ARIA III device. The percentage of cells distributed in different phases, sub-G0, G0/G1, S and G2/M, were calculated using the built-in analysis software. Quantitative Reverse-Transcriptase Polymerase Chain Reaction (qRT-PCR): The protein expression of BAX and BCL2 and P53 were evaluated by qRT-PCR. Total RNA was isolated from brainstem tissues using the High Pure RNA Isolation Kit, according to the manufacturer's instructions. The Transcriptor First Strand c-DNA Synthesis Kit was used to generate c-DNA from RNA, according to the manufacturer's instructions.

Statistical analysis: All in vitro studies were carried out in triplicate and results are expressed as means \pm SD. Statistical significance between groups was evaluated with Tukey-HSD for post-hoc multiple comparisons. $p<0.05$ was considered statistically significant.

\section{Results}

1. Findings of Combination Analysis in Tamoxifen + Vitamin D: Concentrations after $48 \mathrm{~h} 20 \mu \mathrm{M}$ TAM $(p<0.001)$ continued to decrease cell proliferation. The increase in cell proliferation with $50 \mathrm{nM}$ and $100 \mathrm{nM}$ vit $\mathrm{D}(p=0.429, p=0.881$ respectively) and decrease in cell proliferation with $10 \mu \mathrm{M}$ $\operatorname{TAM}(p=0.092))$ were not statistically significant. For $20 \mu \mathrm{M} \mathrm{TAM}+100 \mathrm{nM}$ vit $\mathrm{D}(p=0,01), 20 \mu \mathrm{M}$ $\mathrm{TAM}+50 \mathrm{nM}$ vit $\mathrm{D}(p=0,001), 10 \mu \mathrm{M}$ TAM + $100 \mathrm{nM}$ vit $\mathrm{D}(p=0,002)$ and $10 \mu \mathrm{M} \mathrm{TAM}+50 \mathrm{nM}$ Vit $\mathrm{D}(p=0,005)$ combinations, cell proliferation were significantly decreased. After $72 \mathrm{~h}$ of cytotoxicity experiment, $(20 \mu \mathrm{M}$ TAM $+100 \mathrm{nM}$ vit $\mathrm{D}(p<0,001), 20 \mu \mathrm{M}$ TAM $+50 \mathrm{nM}$ vit $\mathrm{D}(p<0.001), 10 \mu \mathrm{M}$ $\mathrm{TAM}+100 \mathrm{nM}$ vit $\mathrm{D}(p<0.001), 10 \mu \mathrm{M} \mathrm{TAM}+50 \mathrm{nM}$ vit $\mathrm{D}(p<0.001))$ cell proliferation rate were decreased. Moreover, $20 \mu \mathrm{M}$ TAM $(p<0.001)$ and $10 \mu \mathrm{M}$ TAM $(p=0.033)$ administration also decreased cell proliferation (Figure 1).

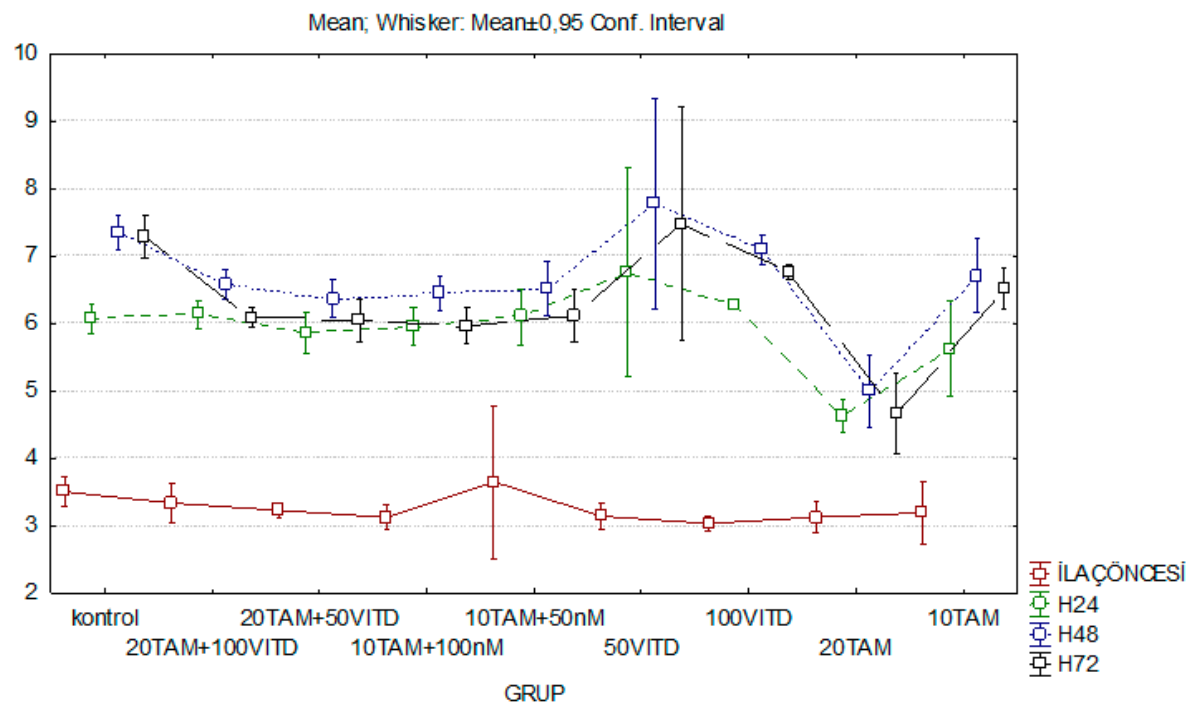

Figure 1. Graph of time-dependent variation of the cell index of Tamoxifen, vitamin D and Tamoxifen + vit D combination at different concentrations between the 24th, 48th and 72th hours. 
2. Demonstration of DNA Damage by Cell Cycle Analysis: When the G1 stage (57\%) of the control group was compared with the other groups $48 \mathrm{~h}$ after the combination experiment, the differences between the averages of $20 \mu \mathrm{M}$ TAM (84\%), $50 \mathrm{nM}$ Vit D (82\%), $20 \mu \mathrm{M}$ TAM+ $50 \mathrm{nM}$ Vit D (91\%), $20 \mu \mathrm{M}$ TAM+ $100 \mathrm{nM}$ Vit $\mathrm{D}(88 \%)$ groups were found to be statistically significant $(p<0.05)$ (Data not shown). The change in the $S$ phase of control group (34\%) and the other groups were examined and the difference between the groups was found to be statistically significant $(p<0.05)$. Moreover, the difference between $20 \mu \mathrm{M}$ TAM group compared to $20 \mu \mathrm{M}$ TAM $+100 \mathrm{nM}$ Vit $\mathrm{D}, 10 \mu \mathrm{M}$ TAM +100 $\mathrm{nM}$ Vit $\mathrm{D}, 10 \mu \mathrm{M}$ TAM $+50 \mathrm{nM}$ Vit D combination groups were found to be statistically significant $(p<0.05)$. G2 phase measurements showed statistically significant differences between dose groups $(p=0.001) .72 \mathrm{~h}$ after combination administration, The mean differences between the $\mathrm{G} 1$ and $\mathrm{S}$ phase of the control group and that of the $20 \mu \mathrm{M}$ TAM, $100 \mathrm{nM}$ Vit D, $20 \mu \mathrm{M}$ TAM $+50 \mathrm{nM}$ Vit D, $10 \mu \mathrm{M}$ TAM $+50 \mathrm{nM}$ Vit D, $10 \mu \mathrm{M}$ TAM $+100 \mathrm{nM}$ Vit D groups were found to be statistically significant $(p<0.05)$. Moreover mean differences between $20 \mu \mathrm{M}$ TAM and $20 \mu \mathrm{M}$ TAM $+100 \mathrm{nM}$ Vit D groups were found to be statistically significant $(p<0.05$ The mean differences between the G2 phase of the control and other groups were not found to be statistically significant $(p=1.256, p=0.306)$ (Data not shown).

3. The Effect of Tamoxifen and Vitamin D on p53, Bcl-2 and Bax Gene Expressions: Statistically significant differences in fold change of the mRNA expression levels of Bax, Bcl-2, p53 in MCF-7 cells as compared with the untreated cells by real-time PCR is shown $(p<0.05)$ (Figure 2). $48 \mathrm{~h}$ after the combination application, p53 gene expression levels were decreased in $10 \mu \mathrm{M}$ and $20 \mu \mathrm{M}$ TAM, $50 \mathrm{nM}$ Vit D, compared to the control group, whereas their expression increased to $72 \mathrm{~h}$. However, the change in the expression of the combination groups at $72 \mathrm{~h}$ was higher than in the other groups. At the 48th hour, Bcl-2 expression of all combination groups increased compared to the control group. At the $72 \mathrm{nd}$ hour, the expression level in the $20 \mu \mathrm{M}$ TAM $+100 \mathrm{nM}$ vit $\mathrm{D}$ group increased significantly compared to the 48th hour. After $48 \mathrm{~h}$, the expression of Bax in $20 \mu \mathrm{M}$ TAM+ 50 vit D, $20 \mu \mathrm{M}$ TAM $+100 \mathrm{nM}$ vit D groups were found to be increased. After $72 \mathrm{~h}$, Bax expression was increased in all combination groups, while it was decreased in $20 \mu \mathrm{M}$ TAM+ $100 \mathrm{nM}$ vit D group (Figure 2).

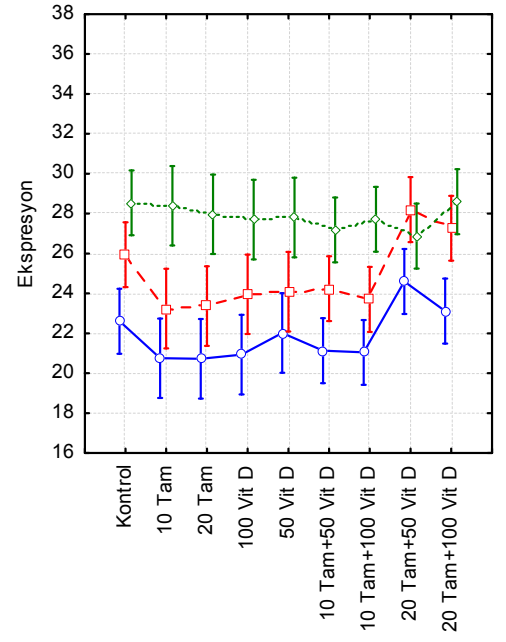

$48 \mathrm{~h}$

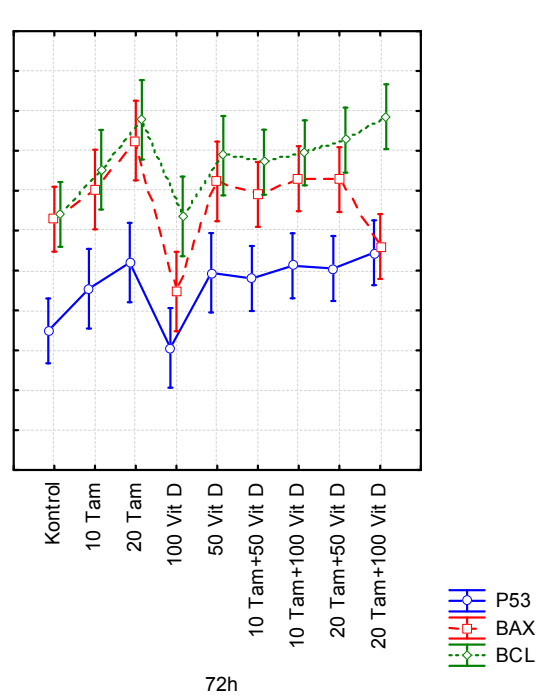

$72 \mathrm{~h}$

Figure 2. Evaluation of the effects of Tamoxifen (TAM) or vitamin D (Vit D), and combinations of both for 48th and 72nd h on the P53, BCL2 and BAX expression levels using qRT-PCR.

\section{Discussion \& Conclusions}

In our study, low concentrations of Tamoxifen and vitamin D were found to increase proliferation of cancer cells. An effective concentration for Tamoxifen was found. It was also found that vitamin D did not decrease cell proliferation alone but decreased cell proliferation when used in combination with Tamoxifen. In conclusion, it was found that therapies using these two agents in different combinations reduce the proliferation of cancer cells and induce cell cycle arrest at G0/G1 
phase. In addition, depending on the expression results of p53, Bcl-2 and Bax, it was found that combination groups were more effective in directing the cells to apoptosis.

\section{References}

1. Özmen, V. Breast Cancer Screening: Current Controversies. J. Breast Health 2011, 7, 1-4.

2. Parkin, D.M.; Bray, F.; Ferlay, J.; Pisani, P. Global Cancer Statistics, 2002. CA Cancer J. Clin. 2005, 55, 74-108.

3. Campbell, J.B. Breast Cancer-Race, Ethnicity, and Survival: A literature Review. Breast Cancer Res. Treat. 2002, 74, 187-192.

4. Lundqvist, J.; Christina, W.Y.; Lykkesfeldt, A.E. 1 $\alpha, 25$-Dihydroxyvitamin D3 inhibits cell growth and $\mathrm{NF \kappa B}$ signaling in tamoxifen-resistant breast cancer cells. Steroids 2014, 85, 30-35.

5. Manjer, J.; Berglund, B.L.; Garne, J.P.; Janzon, L.; Malina, J. Breast Cancer Incidence in Relation to Smoking Cessation. Breast Cancer Res. Treat. 2000, 61, 121-129.

6. Liu, Y.; Colditz, G.A.; Rosner, B.; Berkey, C.S.; Collins, L.C.; Schnitt, S.J.; Connolly, J.L.; Chen, W.Y.; Willett, W.C.; Tamimi, R.M. Alcohol intake between menarche and first pregnancy: A prospective study of breast cancer risk. J. Natl. Cancer Inst. 2013, 105, 1571-2578.

(C) 2018 by the authors. Licensee MDPI, Basel, Switzerland. This article is an open access article distributed under the terms and conditions of the Creative Commons Attribution (CC BY) license (http://creativecommons.org/licenses/by/4.0/). 